\title{
HUKUM DAN HAK PASIEN DALAM MENDAPATKAN PELAYANAN KESEHATAN DI ERA PANDEMIK
}

\author{
Dwi Utoro ${ }^{1 凶}$ \\ ${ }^{1}$ Magister Hukum, Fakultas Hukum Universitas Sebelas Maret, Surakarta, Indonesia \\ Jln. Ir. Sutami, No. 36A, Surakarta, Jawa Tengah 57126- Phone 0271-642595 \\ \dwiutoro@gmail.com
}

\begin{abstract}
The whole world community agrees that the right to health is a basic right (Fundamental Right) that is owned by every human being. The right to health which was previously seen as merely a private matter related to the fate or gift of God, has now undergone a very large paradigm shift into a legal right (legal rights) which is certainly guaranteed by the state. In the midst of the Covid-19 pandemic that has spread to almost all regions of Indonesia, the Government must be prepared to issue various strategic policies so that it can carry out its obligations to always guarantee the fulfillment of the right to health for all people. This research uses the method of library research with the statutory approach. This research found that the Government's policy to determine the Public Health Emergency status and choosing Large-Scale Social Restrictions as an option to respond to Public Health Emergency is a wise step, besides the Government must also pay attention to the economic and fiscal sectors according to the conditions and capabilities of the country.
\end{abstract}

Keywords: Right to health, health service, Pandemic Covid-19.

Di tengah pandemi Covid-19 yang telah menyebar hampir ke seluruh wilayah Indonesia, Pemerintah harus sigap mengeluarkan berbagai kebijakan strategis agar dapat menjalankan kewajibannya untuk senantiasa menjamin terpenuhinya hak atas kesehatan bagi seluruh masyarakat. Penelitian ini menggunakan metode penelitian kepustakaan dengan pendekatan peraturan perundang-undangan. Penelitian ini menemukan bahwa Pemerintah terlalu lamban mengambil tindakan antisipatif maupun mitigasi dalam menanggulangi pandemi corona. Pada akhirnya Pemerintah menetapkan status Darurat Kesehatan Masyarakat dan memilih Pembatasan Sosial Berskala Besar sebagai opsi untuk merespons Kedaruratan Kesehatan Masyarakat, disamping Pemerintah juga tetap harus memperhatikan sektor ekonomi dan fiskal sesuai kondisi dan kemampuan negara.

Kata Kunci: Hak Pasien, Pelayanan Kesehatan, Pandemi Covid-19. 


\section{INTRODUCTION}

Wabah corona dengan jenis virus SARS-Cov-2 yang pertama kali dideteksi kemunculannya di Wuhan Tiongkok kini telah menyebar luas ke seluruh belahan dunia. Sebagaimana diketahui bahwa SARS-Cov-2 bukanlah jenis virus baru. Virus SARS-Cov-2 merupakan hasil dari virus lama yang bermutasi membentuk susunan genetik yang baru, singkatnya virus tersebut tetap satu jenis yang sama dan hanya berganti identitas. Virus ini dinamai dengan SARS-Cov-2 karena secara genetik virus corona memiliki hubungan erat dengan virus yang menyebabkan SARS dan MERS. ${ }^{1}$

Covid-19 semula hanya menjadi wabah di kota Wuhan, tidak membutuhkan waktu lama untuk bertransformasi menjadi pandemi yang meresahkan seluruh dunia. Setelah virus corona berhasil menginfeksi lebih dari 118.000 orang pada 114 negara dan menyebabkan 4.291 orang meninggal dunia, Organisasi Kesehatan Dunia (WHO) akhirnya menetapkan wabah virus corona sebagai pandemi global. Di Indonesia sendiri, kasus terinfeksi virus corona pertama kali diumumkan pada 2 Maret 2020. Setelah peristiwa itu, jumlah pasien yang positif terinfeksi terus bertambah.4 Saat ini masyarakat tidak hanya dilanda kegelisahan namun menderita kepanikan yang luar biasa. ${ }^{2}$

Kepanikan masyarakat yang berlebihan terhadap pandemi global ini tidak luput dari sikap pemerintah yang cenderung lamban. Ketidaksigapan pemerintah salah satunya terlihat dari tidak cekatannya pemerintah dalam membentuk Gugus Tugas Nasional Penanggulangan Virus Corona. Pemerintah pusat baru selesai membentuk tim tersebut pada 14 Maret 2020,5 yang artinya Pemerintah membutuhkan waktu hampir dua minggu hanya untuk membentuk tim penanggulangan virus tersebut. Hal tersebut telah mendorong pemerintah daerah terpaksa terlebih dahulu mengambil langkah mitigasi tanpa melibatkan pemerintah pusat. Polemik baru pun muncul, karena berdasarkan hukum yang berlaku penanganan pandemi global ini berada di bawah satu kordinasi dan pemerintah pusatlah yang berwenangan menentukan kebijakan. ${ }^{3}$

Kebijakan yang dikeluarkan pemerintah adanya Social Distancing yang dimungkinkan untuk mengurangi atau menghambat penyebaran virus. Dan kebijakan ini sangat efektif dengan mencegah orang sakit melakukan kontak langsung kepada orang lainnya yang tidak sakit sehingga mencegah penularan. Begitu juga tenaga kesehatan berupaya mencegah untuk bertambahnya orang yang terifeksi dan perlu adanya jaminan perlindungan dan keselamatan kerja bagi tenaga medis dalam penanganan Corona Virus Disease 2019 (COVID-19). Kebijakan terkait pelayanan kesehatan dapat dikatakan sebagai aspek penting dalam kondisi dimasyarakat sekarang. ${ }^{4}$

Dalam hal ini, Penegakan Hukum di awal munculnya virus di Indonesia. Pemerintah Indonesia di tinjau berdasarkan Pasal 154 Undang-Undang Nomor 36 tahun 2009

1 Otih Handayani, 'Implementation of Prudential Principles in the Use of Disinfectants as an Effort to Prevent Covid-19 Pandemic for Legal Protection of Ecosystems', Journal of Morality and Legal Culture (JMCL ), 1.1 (2020), 58-65 <https://doi.org/10.20961/jmail.17i1.41087>.

2 Sulistya Eviningrum, 'Educative Penalty System as a Protection Implementation for Children Who Commit Crime', Journal of Morality and Legal Culture (JMCL), 1.1 (2020), 38-44 < https://doi.org/10.20961/jmail.17i1.41087>.

${ }^{3}$ Rosidi Ruslan, 'COVID-19 Fulfilling Workers 'Economic Rights Positive', Journal of Morality and Legal Culture (JMCL), 1.2 (2020), 93-102 < https://doi.org/10.20961/jmail.17i1.41087>.

4 Mustika Larasati and Arief Suryono, 'TINJAUAN YURIDIS ASURANSI JIWA TERHADAP KESELAMATAN', Jurnal Pasca Sarjana Hukum UNS, VII.2 (2019), 236-42. 
tentang Kesehatan, menyatakan Pemerintah wajib mengumumkan bagian wilayah yang menjadi sumber terjangkitnya penularan penyakit ke banyak masyarakat. Pemerintah wajib mengungkap jenis dari penyakit yang penularannya menyebar dengan cepat. Fakta dari Pemerintah dalam melindungi jaminan kesehatan masyarakat dikatakan lamban untuk menyebarkan informasi terkait kasus yang memakan korban banyak karena adanya virus yang sangat berbahaya ini. Sehingga dalam Pelayanan Kesehatan yang dilakukan tenaga medis bisa dikatakan hamper tidak mampu karena disebabkan banyaknya pasien yang dinyatakan Positif COVID-19. Berdasarkan uraian diatas, maka akan dibahas mengenai bagaimana awal terjadinya penyebaran virus begitu cepat di inodnesia dan bagaimana pelayanan kesehatan untuk masyarakat Indonesia dengan adanya keterlambatan informasi dalam mengungkapkan terjadinya penyebaran virus COVID-19.5

\section{DISCUSSION}

Manusia akan kehilangan segala kemungkinan untuk mendapatkan hak-hak lainnya tanpa didasari kesehatan. Oleh karenanya kesehatan menjadi salah satu kebutuhan dasar manusia.13 Pengakuan dan perlindungan hak atas kesehatan tersebut diatur secara konstitusional. Sejak masa berlakunya Konstitusi Republik Serikat 1949, hak atas kesehatan telah diatur pada pasal 40 yang berbunyi sebagai berikut: "Penguasa senantiasa berusaha dengan sungguh-sungguh memajukan kebersihan umum dan kesehatan rakyat."14 Pengaturan hak atas kesehatan pada pasal 40 Konstitusi Republik Indonesia Serikat tersebut kemudian di adopsi oleh Pasal 42 Undang-Undang Dasar Sementara. ${ }^{6}$

Kemudian setelah berlakunya UUD NRI Tahun 1945, hak atas kesehatan kembali diatur pada Pasal $28 \mathrm{H}$ ayat (1) dengan norma sebagai berikut: “...setiap orang berhak hidup sejahtera lahir dan batin, bertempat tinggal, dan mendapatkan lingkungan hidup yang baik dan sehat serta berhak memperoleh pelayanan kesehatan...". Sebagai atribut ketentuan tersebut Pasal 4 Undang-Undang Nomor 36 Tahun 2009 tentang Kesehatan menyatakan bahwa "Setiap orang berhak atas kesehatan" secara garis besar UndangUndang tersebut mengisyaratkan bahwa setiap individu, keluarga dan masyarakat berhak memperoleh perlindungan terhadap kesehatannya, dan negara bertanggung jawab mengatur agar terpenuhi hak hidup sehat bagi penduduknya termasuk bagi masyarakat miskin dan tidak mampu. Masuknya ketentuan tersebut ke dalam UndangUndang Dasar 1945 dan Undang-Undang Kesehatan, menggambarkan perubahan paradigma yang luar biasa. Kesehatan tidak lagi hanya dikaitkan dengan nasib atau karunia Tuhan yang menjadi urusan pribadi setiap orang dan sama sekali tidak ada hubungannya dengan tanggung jawab negara, namun saat ini kesehatan telah menjadi suatu hak hukum (legal rights) yang dijamin, dilindungi, dihormati dan harus dipenuhi oleh negara. Hal tersebut sangat jelas tercermin kembali pada pasal 28I ayat (4) UUD 1945 yang menegaskan bahwa

\footnotetext{
${ }^{5}$ Sri Pujiningsih, 'Policy Polemic for Covid 19 and Efforts to Handling Information Technology', Journal of Morality and Legal Culture (JMCL), 1.2 (2020), 93-102 < https://doi.org/10.20961/jmail.17i1.41087>.

6 Yatini, Hari Purwadi, and Hartiwiningsih, 'Reformulasi Konstruksi Pidana Dalam Menjerat Pelaku Tindak Pidana Korporasi', Pasca Sarjana Hukum UNS, VII.1 (2019), 144-52.
} 
Perlindungan, pemajuan, penegakan, dan pemenuhan hak asasi manusia adalah tanggung jawab negara, terutama pemerintah. ${ }^{7}$

Tidak hanya di Indonesia, masyarakat global melalui Konstitusi World Health Organization (WHO) 1946 pun telah menggariskan bahwa "memperoleh derajat kesehatan yang setinggi-tingginya adalah suatu hak asasi bagi setiap orang" (the enjoyment of the highest attainable standard of health is one of the fundamental rights of every buman being). Berdasarkan hal tersebut hak atas kesehatan diakui sebagai "hak dasar" atau "fundamental right". Adanya hak atas kesehatan sebagai fundamental right kemudian dipertegas dalam komentar umum dari Komite Hak-hak Ekonomi, Sosial, dan Budaya terhadap hak atas kesehatan yang menyatakan "Health is a fundamental human right indispensable for the exercise of other human rights." Komentar umum dari Komite Hak-hak Ekonomi, Sosial, dan Budaya, tersebut memberikan titik tekan pada ditempatkannya hak atas kesehatan sebagai hak asasi manusia yang fundamental dan patut didahulukan demi terlaksananya hak asasi manusia yang lainnya. ${ }^{8}$

Sudah selayaknya hak atas kesehatan dihormati dan dilaksanakan oleh Negara sebagai salah satu hak yang mendasar (fundamental). Kewajiban negara dalam memberikan perlindungan terhadap hak atas kesehatan yang dimiliki oleh seluruh warga negara sejalan dengan apa yang dinyatakan oleh WHO yaitu negara dalam hal ini pemerintah mempunyai tanggung jawab terhadap kesehatan dari warga negaranya. Menurut WHO, "government has a responsibility for the health of their people which can be fulfilled only by the provision of adequate health and social measures."18 Tanggung jawab negara untuk memenuhi hak atas kesehatan sebagai hak fundamental dipertegas kembali deklarasi Alamat. Penegasan tersebut tertera pada kalimat berikut: The important WHO and UNICEF Declaration of Almaata adopted at the International Conference on Primary Health Care in 1978, also used similar language: The Conference strongly reaffirms that health, which is a state of complete physical, mental and social wellbeing, and not merely the absence of disease or infirmity, is a fundamental buman right and that the attainment of the highest possible level of health is a most important world-wide social goal whose realization requires the action of many other social and economic sectors in addition to the health sector. ${ }^{9}$

Dalam deklarasi yang dilakukan oleh WHO dan UNICEF tersebut menegaskan kembali hak atas kesehatan yang merupakan bagian dari hak asasi manusia, dengan demikian pemenuhan hak atas kesehatan merupakan tanggung jawab negara dan tujuan dari seluruh dunia yang juga harus didukung oleh berbagai sektor. Melalui beragam kebijakannya seperti penyediaan sistem jaminan kesehatan, penyediaan infrastruktur kesehatan, optimalisasi sumber daya manusia sebagai tenaga medis, merupakan salah satu bentuk upaya negara untuk memenuhi derajat kesehatan masyarakat secara luas. Begitu pula halnya di tengah pandemi penyakit, tanggung jawab negara memelihara kesehatan masyarakat menjadi semakin ekstra. Negara harus mengoptimalkan alokasi keuangan negara, mengoptimalkan regulasi yang tersedia, dan tidak lupa menjaga para tenaga media sebagai garda terdepan. Berhasil atau tidaknya negara menangani pandemi corona ini

7 Suprianto, Agus Riwanto, and Sunny Ummul Firdaus, Implementasi Peraturan Pemerintah Nomor 18 Tahun 2016 Tentang Perangkat Daerah Terhadap Efektivitas Kinerja Pegawai Sekretariat Daerah Dewan Perwakilan', Jurnal Pasca Sarjana Hukum UNS, VII.1 (2019), 134-43.

${ }^{8}$ Isharyanto Bahar Elfudllatsani and Agus Riwanto, 'Kajian Mengenai Kebebasan Berkumpul Dan Berserikat Organisasi Kemasyarakatan Kaitannya Dengan Teori Kedaulatan Rakyat Dan Hak Asasi Manusia', Jurnal Pasca Sarjana Hukum UNS, VII.1 (2019), 52-61.

${ }^{9}$ Eviningrum. 
menunjukkan berhasil tidaknya negara menjaga kesehatan masyarakat yang menjadi tanggung jawabnya.10 Pemerintah dinilai terlambat mengantisipasi corona virus Kepala Pusat Pengendalian Operasi BNPB Bambang Surya Putra mengatakan, keterlambatan merespons masalah COVID-19, ternyata memengaruhi proses pendataan dan manajemen komunikasi publik. Imbasnya, Indonesia sulit memperoleh berbagai peralatan ihwal penanganan COVID-19. Di sisi lain, Gugus Tugas baru dibentuk pada 13 Maret 2020, berdasarkan Keputusan Presiden Nomor 7 Tahun 2020 tentang Gugus Tugas Percepatan Penanganan Corona Virus Disease 2019.11

Kemudian diturunkan dalam Keputusan Kepala Badan Nasional Penanggulangan Bencana Nomor 13 Keterlambatan merespons kemudian berdampak kepada kesulitan memperoleh peralatan yang dibutuhkan untuk melawan COVID-19. Sehingga pemerintah melakukan segala cara. Dari mulai berdiplomasi ke berbagai negara, lewat jalur bisnis atau komersial, hingga berhubungan dengan intelijen. Indonesia dalam kondisi yang tidak siap dan terkejut dengan kecepatan penularan COVID-19. Ketidaksiapan juga terkait ketersediaan kebutuhan peralatan dan pendataan yang sangat memengaruhi penanganan COVID-19. Hal itu juga memengaruhi komunikasi publik dan pengambilan kebijakan yang tepat. Walhasil, masyarakat bingung harus bersikap seperti apa. Di sisi lain, pendataan juga terkendala ego sektoral dan birokrasi yang panjang. ${ }^{12}$

Upaya penanggulangan berbagai macam seperti pemeriksaan, pengobatan, perawatan, serta melakukan isolasi penderita yang dinyatakan positif begitu juga termasuk tindakan kekarantinaan. Kebijakan Pemerintah telah menerapkan kebijakan Pembatasan Sosial Berskala Besar (PSBB) untuk mencegah semakin meluasnya penularan COVID-19. Penerapan PSBB telah diatur dalam Peraturan Pemerintah Nomor 21 Tahun 2020 yang ditandatangani Presiden pada Selasa (31/3/2020). Sementara itu, detail teknis dan syaratsyarat mengenai PSBB dituangkan dalam Peraturan Menteri Kesehatan (Permenkes) RI Nomor 9 Tahun 2020 tentang Pedoman Pembatasan Sosial Berskala Besar Dalam Rangka Percepatan Penanganan Corona Virus Disease 2019 (COVID-19) yang ditandatangani oleh Menteri Kesehatan RI Terawan Agus Putranto. Adapula pada ketentuan Peraturan Perundang - undangan yang dituangkan dalam Undang-Undang Nomor 6 tahun 2018 tentang Kekarantinaan Kesehatan dapat dikatakan lockdown adlah bagian dari ketentuan yang telah dibuat kebiajakan pada peraturan tersebut, pada peraturan tersebut membahas karatina kesehatan dipintu masuk dan di wilayah dilakukan kegiatan pengamatan penyakit dan berbagai faktor resiko kesehatan masyarakat terhadapa alat angkut, manusia, barang, dan/ lingkungan, serta respon terhadap kedaruratan kesehatan masyarakat dalam bentuk tindakan kekarantinaan kesehatan. ${ }^{13}$

\section{Kebijakan Negara dari Perspektif Law Enforcmen}

\footnotetext{
${ }^{10}$ Febry Wulandari and Waluyo Waluyo, 'Efektivitas Pemanfaatan Dana Bagi Hasil Cukai Hasil Tembakau Dalam Bidang Kesehatan Di Kota Surakarta Tahun 2018', Bestuur, 7.1 (2019), 15-25 <https://doi.org/10.20961/bestuur.v7i1.28418>.

11 Sara Hersiavita, 'UPAYA PENGEMBALIAN KERUGIAN NEGARA DARI PERKARA TINDAK PIDANA KORUPSI OLEH KEJAKSAAN NEGERI SUKOHARJO', Jurnal Hukum Dan Pembangunan Ekonomi, 7.1 (2019), 15-28. 93-105.

${ }^{12}$ Andesgur Ivnaini, ‘Analisa Kebijakan Hukum Lingkungan Dalam Pengelolaan Pestisida', Bestuur, 7.2 (2019),

13 I Gusti Ayu Ketut Rachmi Handayani, Lego Karjoko, and Abdul Kadir Jaelani, 'Model Pelaksanaan Putusan Mahkamah Konstitusi Yang Eksekutabilitas Dalam Pengujian Peraturan Perundang-Undangan Di Indonesia', Bestuur, 7.1 (2019), 36-46.
} 
Sejak tahun 1984 Indonesia telah membentuk aturan hukum mengenai wabah penyakit menular. Melalui Undang-Undang Nomor 4 Tahun 1984 tentang Wabah Penyakit Menular (UU Wabah Penyakit Menular) mendefinisikan wabah penyakit menular sebagai kejadian berjangkitnya suatu penyakit menular dalam masyarakat yang jumlah penderitanya meningkat secara nyata melebihi daripada keadaan yang lazim pada waktu dan daerah tertentu serta dapat menimbulkan malapetaka.20 UU Wabah Penyakit Menular ini menjelaskan terdapat beberapa tindakan tindakan dalam menanggulangi wabah penyakit menular yaitu: penyelidikan epidemiologis, pemeriksaan, pengobatan, perawatan, dan isolasi penderita termasuk tindakan karantina, pencegahan dan pengebalan, pemusnahan penyebab penyakit, penanganan jenazah akibat wabah, penyuluhan kepada masyarakat, dan upaya penanggulangan lainnya. Perlu diperhatikan bahwa penanggulangan penyakit menular harus dilakukan dengan memperhatikan kelestarian lingkungan.14

Dalam hal penegakan hukum, Undang-Undang Nomor 36 Tahun 2009 tentang Kesehatan (UU Kesehatan) telah mengatur apa yang harus dilakukan oleh Pemerintah RI. Berdasarkan UU Kesehatan, Pemerintah RI wajib mengumumkan wilayah yang menjadi sumber penularan penyakit kepada masyarakat. Artinya, pemerintah wajib mengungkapkan secara terbuka jenis dan persebaran penyakit yang berpotensi menular atau menyebar dalam waktu yang singkat serta menyebutkan daerah yang menjadi sumber penularan. Langkah pertama berupa membuka informasi tersebut sangat esensial, karena dengan informasi yang akurat masyarakat dapat melakukan antisipasi dan pencegahan diri serta lebih waspada terhadap penularan virus tersebut. Hal ini menjadi sangat esensial karena tertutupnya informasi akan menyebabkan masyarakat yang tadinya berada dalam zona nyaman, menjadi dilanda kepanikan hebat yang berimbas pada perilaku panic buying. Panic Buying sendiri menimbulkan masalah baru yakni tidak terkendalinya kegiatan pasar yang akan menimbulkan inflasi. ${ }^{15}$

Selain harus terbuka dalam hal pembagian informasi, Pemerintah juga harus menyusun strategi lebih lanjut dalam penanganan pandemi terutama untuk mengantisipasi lonjakan jumlah infeksi yang sudah diprediksi. Dalam hal ini hukum bertindak sebagai alat rekayasa sosial, sehingga harus ditegakkan baik untuk menangani pandemi yang saat ini sedang terjadi, maupun untuk digunakan pada waktu mendatang sebagai langkah pencegahan jika wabah serupa terjadi di kemudian waktu. Skenario hukum ini sangat penting, mengingat wabah maupun pandemi merupakan bencana non alam yang sulit untuk diprediksi, sehingga negara harus senantiasa memiliki langkah antisipasi sehingga negara siap menghadapi bencana yang tidak pernah didugaduga tersebut. Meski belum cukup memadai dan harus terus dilengkapi dan disempurnakan, sesungguhnya Indonesia sendiri memiliki peraturan pelaksana untuk menanggulangi penyakit menular. Peraturan pelaksana tersebut salah satunya adalah Peraturan Menteri Kesehatan No. 82 Tahun 2014 tentang Penanggulangan Penyakit Menular. Pada pasal 8 Peraturan Menteri tersebut dijelaskan tiga langkah penanggulangan yang dapat dilakukan yaitu reduksi, eliminasi dan eradikasi. Tiga

14 Solikah Ana Estikomah, 'Aspek Hukum Import Sampah Plastik', Bestuur, 7.2 (2019), 106 <https://doi.org/10.20961/bestuur.v7i2.40439>.

${ }^{15}$ Lego Karjoko, Zaidah Nur Rosidah, and I Gusti Ayu Ketut Rahmi Handayani, 'Refleksi Paradigma Ilmu

Pengetahuan Bagi Pembangunan Hukum Pengadaan Tanah', Bestuur, $7.1 \quad$ (2019), 1-14 <https://doi.org/10.20961/bestuur.v7i1.42694>. 
langkah ini dilakukan dilakukan ketika wabah yang ada sudah diasumsikan menular. Reduksi adalah upaya pengurangan angka kesakitan atau kematian akibat penyakit menular tertentu agar penyakit tersebut menurun secara bertahap. Eliminasi adalah upaya pengurangan terhadap penyakit secara berkesinambungan di wilayah tertentu sehingga angka kesakitan penyakit dapat ditekan agar tidak menjadi masalah di daerah tertentu. 16

Adapun eradikasi adalah upaya pembasmian yang dilakukan secara berkelanjutan melalui pemberantasan dan eliminasi untuk menghilangkan jenis penyakit menular tertentu secara permanenan sehingga tidak menjadi masalah kesehatan nasional. Menurut Pasal 24 ayat (1) Permenkes ini, perlu dibentuk Tim Gerak Cepat penanggulangan penyakit menular. Apabila merujuk pada Undang-Undang Nomor 24 Tahun 2007 tentang Penanggulangan Bencana (UU Penanggulangan Bencana), maka pandemi corona yang terjadi dewasa ini dapat dikategorikan sebagai bencana non alam. UU Penanggulangan Bencana mengategorikan bencana non alam sebagai bencana yang diakibatkan oleh peristiwa atau rangkaian peristiwa non alam antara lain berupa gagal teknologi, gagal modernisasi, epidemi, dan wabah penyakit. ${ }^{17}$

Dengan demikian wabah corona ini merupakan bencana non alam berupa epidemi dan wabah penyakit. Regulasi yang diatur dalam UU Penanggulangan Bencana ini mengatur penanggulangan pasca peristiwa, yakni menanggulangi risiko yang timbul dari suatu bencana. UndangUndang ini juga menegaskan bahwa Pemerintah Pusat dan pemerintah daerah bertanggung jawab untuk menanggulangi akibat dari adanya bencana alam. Pada tahun 2018, Indonesia telah memiliki peraturan terbaru mengenai karantina kesehatan yang diatur dalam Undang-Undang Nomor 6 Tahun 2018 tentang Karantina Kesehatan (UU Karantina Kesehatan). Dalam UU Karantina Kesehatan tersebut mendefinisikan karantina kesehatan upaya mencegah dan menangkal keluar atau masuknya penyakit dan/atau faktor risiko kesehatan masyarakat yang berpotensi menimbulkan kedaruratan kesehatan masyarakat.Untuk dapat melakukan karantina kesehatan tersebut Pemerintah harus menetapkan bahwa negara berada dalam status Darurat Kesehatan Masyarakat. Kedaruratan Kesehatan Masyarakat merupakan kejadian kesehatan masyarakat yang bersifat luar biasa dengan ditandai penyebaran penyakit menular dan/atau kejadian yang disebabkan oleh radiasi nuklir, pencemaran biologi, kontaminasi kimia, bioterorisme, dan pangan yang menimbulkan bahaya kesehatan dan berpotensi menyebar lintas wilayah atau lintas negara. Pasal 3 UU Karantina Kesehatan menjelaskan bahwa Penyelenggaraan Kekarantinaan Kesehatan bertujuan untuk melindungi masyarakat dari penyakit dan/atau Faktor Risiko Kesehatan Masyarakat yang berpotensi menimbulkan Kedaruratan Kesehatan Masyarakat, mencegah dan menangkal penyakit dan/atau Faktor Risiko Kesehatan Masyarakat yang berpotensi menimbulkan Kedaruratan Kesehatan Masyarakat, meningkatkan ketahanan nasional di bidang kesehatan masyarakat, dan memberikan pelindungan dan kepastian hukum bagi masyarakat dan petugas kesehatan. Hal yang menjadi titik tekan pada penyelenggaraan karantina kesehatan ini ialah Pemerintah

16 Arif Dian Santoso, Adi Sulistiyono, and Isharyanto, 'Majelis Kehormatan Disiplin Kedokteran Indonesia ( Mkdki ) Untuk Dapat Menjamin Keadilan Dalam Hubungan Dokter Dan Pasien', Jurnal Pasca Sarjana Hukum UNS, VII.1 (2019), 29-38.

17 Yatini, Purwadi, and Hartiwiningsih. 
Pusat dan Pemerintah Daerah bertanggung jawab terhadap ketersediaan sumber daya yang diperlukan dalam penyelenggaraan Kekarantinaan Kesehatan.18

Terdapat empat jenis karantina kesehatan yang diatur dalam UU Karantina Kesehatan, yaitu karantina rumah, karantina rumah sakit, karantina wilayah, dan pembatasan sosial berskala besar. Empat jenis karantina tersebut dilakukan dalam rangka memitigasi faktor risiko di wilayah pada situasi Kedaruratan Kesehatan Masyarakat. Adapun karantina Rumah adalah pembatasan penghuni dalam suatu rumah beserta isinya yang diduga terinfeksi penyakit dan/atau terkontaminasi sedemikian rupa untuk mencegah kemungkinan penyebaran penyakit atau kontaminasi. Selanjutnya dijelaskan Karantina Rumah Sakit adalah pembatasan seseorang dalam rumah sakit yang diduga terinfeksi penyakit dan/atau terkontaminasi sedemikian rupa untuk mencegah kemungkinan penyebaran penyakit atau kontaminasi. Sedangkan yang dimaksud Karantina Wilayah adalah pembatasan penduduk dalam suatu wilayah termasuk wilayah pintu Masuk beserta isinya yang diduga terinfeksi penyakit dan/atau terkontaminasi sedemikian rupa untuk mencegah kemungkinan penyebaran penyakit atau kontaminasi. Lebih lanjut didefinisikan bahwa Pembatasan Sosial Berskala Besar adalah pembatasan kegiatan tertentu penduduk dalam suatu wilayah yang diduga terinfeksi penyakit dan/atau terkontaminasi sedemikian rupa untuk mencegah kemungkinan penyebaran penyakit atau kontaminasi. ${ }^{19}$

Dalam hal menentukan Karantina Rumah, Karantina Wilayah, Karantina Rumah Sakit, atau Pembatasan Sosial Berskala Besar yang akan dipilih sebagai tindakan untuk merespons Kedaruratan Kesehatan Masyarakat harus didasarkan pada pertimbangan epidemiologis, besarnya ancaman, efektivitas, dukungan sumber daya, teknis operasional, pertimbangan ekonomi, sosial, budaya, dan keamanan. Dengan demikian ketentuan-ketentuan di atas merupakan payung hukum yang masih memerlukan berbagai peraturan pelaksana. Menggunakan peraturan pelaksana itulah baik pemerintah pusat maupun pemerintah daerah akan berpedoman dalam melaksanakan karantina kesehatan itu sendiri. ${ }^{20}$ Sebagai aturan pelaksana dari UU Karantina Kesehatan Pemerintah telah menerbitkan Peraturan Pemerintah Nomor 21 Tahun 2020 tentang Pembatasan Sosial Berskala Besar dalam Rangka Percepatan Penanganan Corona Virus Disease 2019 (COVID-19). Namun jika ditelaah secara komprehensif, materi muatan yang diatur pada Peraturan Pemerintah tersebut hanya sebatas mengatur prosedur penetapan Pembatasan Sosial Berskala Besar melalui kewenangan Pemerintah Daerah, Gugus Tugas Percepatan Penanganan Corona Virus Disease (Covid-19), dan Pemerintah Pusat dalam hal ini Kementerian Kesehatan. ${ }^{21}$

Pengaturan secara rinci yang menggambarkan materi muatan suatu peraturan pelaksana justru tidak termuat dalam peraturan pemerintah tersebut. seperti halnya penutupan, penjagaan, pengamanan, dan pembatasan akses keluar masuk suatu wilayah,

18 C.D. Balenina, 'Partisipasi Masyarakat Dalam Pengelolaan Desa Sampah Mandiri Di Desa Kalisoro, Tawangmangu, $\quad$ Kabupaten $\quad$ Karanganyar', $\quad B e s t u u r, \quad 7.1 \quad$ (2019), $\quad 26-35$ <https://jurnal.uns.ac.id/bestuur/article/view/17392>.

19 Eni Muryani, 'Sinergisitas Penegakan Hukum Pada Kasus Pertambangan Emas Tanpa Izin Di Kabupaten Banyumas, Jawa Tengah', Bestuur, 7.2 (2019), 84 <https://doi.org/10.20961/bestuur.v7i2.40437>.

20 Arif Jumari, 'Potensi Pelanggaran Pengelolaan Limbah Bahan Berbahaya Dan Beracun Arif, Bestuur, 7.2 (2019), 76-83.

${ }^{21}$ Handayani, Karjoko, and Jaelani. 
tata cara pemenuhan kebutuhan dasar masyarakat selama pembatasan sosial berskala besar, serta prosedur teknis dan prosedur sistematis untuk menangani virus corona justru tidak disinggung dalam peraturan pemerintah tersebut. Tidak hanya itu, jika diperhatikan dari segi penggunaan addresat Peraturan Pemerintah tersebut hanya ditujukan untuk penanganan pandemic Covid-19, artinya Peraturan Pemerintah ini tidak dapat digunakan untuk menangani pandemi atau wabah penyakit menular lainnya. Padahal semestinya, adanya peraturan pemerintah ini diperuntukkan untuk menjadi peraturan pelaksana dari UU Karantina Wilayah selama UU karantina wilayah ini masih berlaku. Sehingga dengan demikian, apabila pandemi seru terjadi dikemudian hari Pemerintah telah memiliki pedoman pelaksanaan yang pasti untuk melakukan penanganan. Segala kebijakan hukum yang dipilih oleh pemerintah tentu harus bertujuan untuk kemaslahatan masyarakat terutama di bidang kesehatan. ${ }^{22}$

Dalam wabah ini kesehatan dan keselamatan masyarakat sangat terancam sehingga Pemerintah harus sangat hati-hati mengambil tindakan apa pun agar tidak berimbas pada kerugian masyarakat. Penting kiranya juga untuk memperhatikan prinsip kepastian hukum tidak hanya dalam menjamin keselamatan masyarakat pada umumnya, melainkan Perintah pula harus menjadi garda terdepan yang melindungi para tenaga medis yang tengah berjuang mengobati ribuan pasien yang terinfeksi virus corona. Terlebih jika melihat peraturan perundang-undangan mengenai tenaga kesehatan nyatanya belum terdapat pengaturan lebih lanjut dari Undang-undang Nomor 36 Tahun 2014 tentang Tenaga Kesehatan (UU Tenaga Kesehatan) yang memberikan penjaminan kepastian hukum bagi tenaga kesehatan. Dengan demikian Pemerintah perlu dengan sigap menerbitkan peraturan pelaksanaan dan petunjuk teknis UU Tenaga kesehatan dan undang-undang lainnya yang mengatur tentang perlindungan hukum dan keselamatan kerja bagi Tenaga kesehatan. ${ }^{23}$

\section{Hubungan hukum antara Pasien dengan Tenaga Medis (dokter) dalam memberikan pelayan kesehatan}

Hubungan hukum antara dokter dengan pasien telah terjadi sejak dahulu (zaman Yunani kuno), dokter sebagai seorang yang memberikan pengobatan terhadap orang yang membutuhkannya. Hubungan ini merupakan hubungan yang sangat pribadi karena didasarkan atas kepercayaan dari pasien terhadap dokter yang disebut dengan transaksi terapeutik. Transaksi terapeutik adalah perjanjian antara dokter dan pasien berupa hubungan hukum yang melahirkan hak dan kewajiban kedua belah Pihak. Objek dari perjanjian ini adalah berupa upaya atau terapi untuk menyembukan pasien. Hubungan hukum antara dokter dengan pasien ini berawal dari pola hubungan vertikal paternalistik seperti antara bapak dengan anak yang bertolak dari prinsip "father knows best' yang melahirkan hubungan yang bersifat paternalistik. Hubungan hukum timbul bila pasien menghubungi dokter karena ia merasa ada sesuatu yang dirasakannya membahayakan kesehatannya. Keadaan psikobiologisnya memberikan peringatan bahwa ia merasa sakit, dan dalam hal ini dokterlah yang dianggapnya mampu

22 M Jamil, 'Pemalsuan Akta Autentik Sebagai Aspek Pidana Notaris M.Jamil', Bestuur, 7.2 (2019), 114-21.

23 Iswantoro, 'Juridical Analysis of Environmental Law Enforcement in Forestry Crimes Regulation in the Regional Autonomy Iswantoro', Journal of Morality and Legal Culture ( JMCL ), 1.1 (2020), 45-49 <https://doi.org/10.20961/jmail.17i1.41087>. 
menolongnya dan memberikan bantuan pertolongan. Jadi, kedudukan dokter dianggap lebih tinggi oleh pasien dan peranannya lebih penting daripada pasien. Hak-hak dokter sebagai pengemban profesi dapat dirumuskan sebagai berikut. ${ }^{24}$

1. Hak memperoleh informasi yang selengkap-lengkapnya dan sejujurjujurnya dari pasien yang akan digunakannya bagi kepentingan diagnosis maupun terapeutik.

2. Hak atas imbalan jasa atau honorarium terhadap pelayanan yang diberikannya kepada pasien.

3. Hak atas itikad baik dari pasien atau keluarganya dalam melaksanakan transaksi terapeutik.

4. Hak membela diri terhadap tuntutan atau gugatan pasien atas pelayanan kesehatan yang diberikannya.

5. Hak untuk memperoleh persetujuan tindakan medik dari pasien atau keluarganya.

Hak-hak tersebut di atas, dokter juga mempunyai kewajiban yang harus dilaksanakan yaitu sebagai berikut:

1. Kewajiban untuk memberikan pelayanan medis sesuai dengan standar profesi, yaitu dengan cara melakukan tindakan medis dalam suatu kasus yang konkret menurut ukuran tertentu yang didasarkan pada ilmu medis dan pengalaman.

2. Kewajiban untuk menghormati hak-hak pasien, antara lain rahasia atas kesehatan pasien bahkan setelah pasien meninggal dunia.

3. Kewajiban untuk memberikan informasi pada pasien dan/atau keluarganya tentang tindakan medis yang dilakukannya dan risiko yang mungkin terjadi akibat tindakan medis tersebut.

4. Kewajiban merujuk pasien untuk berobat ke dokter lain yang mempunyai keahlian/kemampuan yang lebih baik.

5. Kewajiban untuk memberikan pertolongan dalam keadaan darurat sebagai tugas perikemanusiaan

\section{Tanggung Jawab Hukum Dokter Terhadap Pasien}

Dokter sebagai tenaga professional bertanggung jawab dalam setiap tindakan medis (dokter) yang dilakukan terhadap pasien. Dalam menjalankan tugas profesionalnya didasarkan pada niat baik yaitu berupaya dengan sungguh-sungguh berdasarkan pengetahuannya yang dilandasi dengan sumpah dokter, kode etik kedokteran dan standar profesinya untuk menyembuhkan atau menolong pasien. Antara lain adalah: Tanggung Jawab Etis : terjadinya Wanprestasi atau perbuatan melawan hukum dari tindakan dokter, menurut Pasal 1426 KUH Perdata ganti rugi yang dapat dibebankan jika terjadi Wanprestasi adalah, Kerugian yang nyatanyata diderita kreditur yang disebut dengan Damnun Emergens; Keuntungan yang seharusnya diperoleh yang disebut Lucrum Cegans.Pada asasnya bentuk dari ganti rugi

24 Riyan Aditya Nugraha, Widodo Tresno Novianto, and Supanto, 'KARANGANYAR DALAM MEMUTUS PERKARA PIDANA HAK CIPTA GUNA MENCIPTAKAN KEPASTIAN HUKUM CIPTA ( Putusan', Jurnal Pasca Sarjana Hukum UNS, 7.1 (2011), 169-80. 
yang lazim dipergunakan ialah uang, oleh karena menurut ahli-ahli hukum perdata maupun yurisprudensi, uang merupakan alat yang paling praktis, yang paling sedikit menimbulkan selisih dalam menyelesaikan suatu sengketa. Selain uang masih ada bentuk-bentuk lain yang diperlukan sebagai bentuk ganti rugi yaitu pemulihan keadaan semula (innatura) dan larangan untuk mengulangi. Keduanya ini kalau tidak ditepati dapat diperkuat dengan uang paksa. Jadi harus diingat bahwa uang paksa bukan merupakan bentuk atau wujud ganti rugi. ${ }^{25}$

Gugatan untuk membayar ganti rugi atas dasar persetujuan atau perjanjian yang terjadi hanya dapat dilakukan bila memang ada perjanjian dokter dengan pasien. Perjanjian tersebut dapat digolongkan sebagai persetujuan untuk melakukan atau berbuat sesuatu. Perjanjian itu terjadi bila pasien memanggil dokter atau pergi ke dokter, dan dokter memenuhi permintaan pasien untuk mengobatinya. Dalam hal ini pasien akan membayar sejumlah uang. Sedangkan dokter sebenarnya harus melakukan prestasi menyembuhkan pasien dari penyakitnya. Tetapi penyembuhan itu tidak pasti selalu dapat dilakukan sehingga seorang dokter hanya mengikatkan dirinya. untuk memberikan bantuan sedapatdapatnya, sesuai dengan ilmu dan ketrampilan yang dikuasainya. Artinya, dia berjanji akan berdaya upaya sekuat-kuatnya untuk menyembuhkan pasien. Tanggung Jawab Perdata Dokter Karena Perbuatan Melanggar Hukum (onrechtmatige daad) berdasarkan Pasal 1365 KUH Perdata. Adanya tindakan atau perbuatan Unsur-unsur yang tersimpul dari perumusan Pasal 1365 adalah:

1. Perbuatan itu harus melawan hukum (onrecht matigedaad)

2. Pelakunya mempunyai unsur salah

3. Tindakan atau perbuatan itu menimbulkan kerugian. Berdasarkan Pasal 1366 KUH Perdata, seorang dokter selain dapat dituntut atas dasar wanprestasi dan melanggar hukum seperti tersebut di atas, dapat pula dituntut atas dasar lalai, sehingga menimbulkan kerugian. Gugatan atas dasar kelalaian ini diatur dalam Pasal 1366 KUH Perdata, menyatakan : "Setiap orang bertanggung jawab tidak saja untuk kerugian yang disebabkan karena perbuatannya, tetapi juga untuk kerugian yang disebabkan karena kelalaian atau kurang hati-hatinya".

Berdasarkan Pasal 1367 KUH Perdata, apabila kita simpulkan maka dari segi hukum perdata, tanggung jawab tersebut dapat mengandung beberapa aspek yaitu dapat ditimbulkan karena "wanprestasi" (tidak memenuhi prestasi), karena perbuatan melanggar hukum (onrecht matigedaad), dapat juga karena kurang hatihatinya mengakibatkan matinya orang (moedwillige/onrecht matigedoodslag) dan juga karena kurang hati-hatinya mengakibatkan cacat badan.

\section{Hubungan Hukum Dokter dengan Pasien}

Hubungan hukum dokter-pasien akan menempatkan dokter dan pasien berada pada kesejajaran, sehingga setiap apa yang dilakukan oleh dokter terhadap pasien tersebut harus melibatkan pasien dalam menentukan apakah sesuatu tersebut dapat atau tidak dapat dilakukan atas dirinya. Salah satu bentuk kesejajaran dalam hubugan

25 Ahmad Kodir Jailani Tanjung, Hari Purwadi, and Hartiwiningsih, 'Paradigma Hakim Dalam Memutuskan

Perkara Pidana Di Indonesia’, Jurnal Pasca Sarjana Hukum UNS, 7.1 (2019), 39-51 <https://jurnal.uns.ac.id/hpe/article/view/29178>. 
hukum dokter pasien adalah melalui informed consent atau persetujuan tindakan medik. Pasien berhak memutuskan apakah menerima atau menolak sebagian atau seluruhnya rencana tindakan dan pengobatan yang akan dilakukan oleh dokter terhadap dirinya. Undang-Undang Republik Indonesia Nomor 29 Tahun 2004 Tentang Praktik Kedokteran, khusunya mengatur tentang Hak dan Kewajiban Dokter atau tenaga medis, doktcr mempunyai hak :

1. memperoleh perlindungan hukum sepanjang melaksanakan tugas sesuai dengan standar profesi dan standar prosedur operasional;

2. memberikan pelayanan medis menurut standar profesi dan standar prosedur operasional;

3. memperoleh informasi yang iengkap dan jujur dan pasien atau keluarganya;

4. menerima imbalan jasa.

Hubungan hukum dokter pasien yang sesuai Pasal 1320 KUHPerdata yang mengatur syarat-syarat sahnya sebuah perjajiajan atau perikatan hukum Syarat-syarat tersebut yaitu antara lain :

1. Pelaku perjanjian harus dapat bertindak sebagai subjek hukum.

2. Perjanjian antara subjek hukum tersebut harus atas dasar sukarela dan tanpa paksaan.

3. Perjanjian tersebut memperjanjikan sesuatu di bidang pelayanan kesehatan.

4. Perjanjian tersebut harus atas sebab yang halal dan tidak bertentangan dengan hukum.

Hubungan hukum rumah sakit-pasien adalah sebuah hubungan perdata yang menekankan pelaksanaan hak-hak dan kewajiban masing-masing pihak secara timbal balik. Dokter berkewajiban untuk memenuhi hak-hak pasien dan sebaliknya pasien berkewajiban memenuhi hak dokter. ${ }^{26}$ Kegagalan salah satu pihak memenuhi hak-hak pihak lain, apakah karena wanprestasi atau kelalaian akan berakibat pada gugatan atau tuntutan perdata yang berupa ganti rugi atas kerugian yang dialami oleh pasien. Dalam hubungan antara dokter dan pasien sering timbul masalah dengan adanya dugaan terjadinya kelalaian medis, hal itu dapat juga disebabkan karena kurangnya pemahaman atau persepsi yang sama atas hak dan kewajiban baik pemberi dan penerima pelayanan kesehatan. Masalah hukum yang timbul tersebut dapat diakibatkan kesalahan atau kelalaian para petugas kesehatan atau diakibatkan kesalahan dalam menerapkan kebijaksanaan atas peraturan dan juga diakibatkan kekurangan pengetahuan para petugas tentang Hukum Kesehatan atau peraturan perundangundangan dibidang kesehatan.

Perkembangan saat ini masyarakat semakin sadar atas hak-haknya yang secara otomatis menuntut adanya transparansi pelayanan kesehatan, terutama dalam kaitan hubungan dokter dengan pasien dan menyangkut keluhan yang dialami pasien serta terapi, pengobatan yang dilakukan oleh dokter terhadap pasien. Hal yang sangat mendasar dalam pelayanan kesehatan yang selalu dipermasalahkan masyarakat, pasien adalah menyangkut keterbukaan, transparansi, mutu pelayanan, penerapan aturan, kedisiplinan waktu, sehingga sering diduga melakukan kelalaian medis atau musibah

26 Agung Ariyanto, Lego Karjoko, and Isharyanto, 'Politik Hukum Asas Non-Legally Binding Rekomendasi Ombudsman Republik Indonesia Sebagai Instrumen Pencegahan Dan Penanganan Laporan Maladministrasi', Jurnal Pasca Sarjana Hukum UNS, VII.1 (2019), 62-73. 
klinis $^{27}$ Dalam hal ini, rumah sakit harus dapat memberikan perlindungan dan kepastian hukum bagi seluruh tenaga kesehatan yang memberikan pelayanan kesehatan melalui pembentukan berbagai perangkat aturan meliputi, peraturan internal staf medis, standar prosedur operasional dan berbagai pedoman pelayanan kesehatan serta melalui penyediaan SDM yang memiliki kompetensi dalam bidang medikolegal.

Hal lain yang perlu mendapat perhatian bersama oleh seluruh pihak di rumah sakit adalah menyangkut pelaksanaan etika profesi dan etika rumah sakit sehingga penyelenggaraan Pelayanan secara beretika akan sangat mempermudah seluruh pihak dalam menegakkan aturan-aturan hukum. Permasalahan hukum yang dihadapi tenaga medis atau dokter dalam pelayanan medis. Adapun dalam suatu sistem kesehatan, interaksi yang nampak adalah interaksi antara dokter dan pasien yang mungkin juga melibatkan unsur-unsur lainnya. Unsur-unsur lain tersebut mungkin para medis baik bagian perawatan maupun non perawatan, pekerja sosial dan rumah sakit, di mana mereka secara pribadi atau bersama-sama terikat oleh kaidah-kaidah tertentu, baik kaidah-kaidah hukum maupun kaidah sosial lainnya. Sistem kesehatan adalah profesi kedokteran, karena menurut anggapan umum, seseorang yang mempunyai profesi ini adalah menyenangkan, yaitu dianggap merupakan profesi yang mulia. Oleh karena itu perlunya ditinjau kembali Perangkat hukum yang mengatur penyelenggaraan praktik kedokteran dirasakan belum memadai, selama ini masih didominasi oleh kebutuhan formal dan kepentingan pemerintah,sedangkan porsi profesi masih sangat kurang. Dokter dengan perangkat keilmuan yang dimilkinya mempuyai karakteristik yang khas. Kekhasannya ini terlihat dari pembenaran yang diberikan oleh hukum yaitu diperkenankannya melakukan tindakan medik terhadap tubuh manusia dalam upaya memelihara dan meningkatkan derajat kesehatan

\section{CONCLUSION}

Dari hasil penelitian sebagaimana yang dijabarkan sebelumnya, dapat disimpulkan bahwa hak atas kesehatan merupakan hak dasar yang telah diakui dan dilindungi oleh konstitusi. Negara dalam hal ini pemerintah wajib bertanggung jawab penuh atas penjaminan dan perlindungan keselamatan seluruh masyarakat dari adanya pandemi corona Adapun langkah yang harus dilakukan oleh negara dalam hal ini pemerintah sejak awal munculnya informasi mengenai wabah virus atau wabah penyakit menular seperti halnya Covid-19 ialah dengan melakukan penyelidikan epidemiologis, pemeriksaan, pengobatan, perawatan, dan isolasi penderita. Pemerintah juga harus mengumumkan secara terbuka kepada masyarakat mengenai segala hal yang berhubungan dengan pencegahan, penanganan, dan kondisi terkini dari keberadaan virus itu sendiri. Pemerintah harus dengan sigap menyatakan status Darurat Kesehatan Masyarakat dan memilih alternatif karantina kesehatan yang dianggap sesuai dengan kondisi sosial ekonomi negara. Berbagai peraturan pelaksana seperti halnya peraturan pelaksana atas UU Karantina Kesehatan harus segara disusun agar Pemerintah Pusat, Pemerintah Daerah dan Gugus Penanganan Covid-19 memiliki pedoman yang jelas untuk bahu membahu menangani pandemi corona. Peraturan pelaksana atas UU Tenaga Kesehatan juga sangat diperlukan

${ }^{27} \mathrm{~N}$ W Afreeportamara and Pujiyono, 'Hambatan Kurator Dalam Menyelesaikan Piutang Koperasi Yang

Diputus Pailit', Jurnal Hukum Dan Pembangunan Ekonomi, $7.2 \quad$ (2019), 243-50 <https://jurnal.uns.ac.id/hpe/article/view/43014>. 
untuk memberikan jaminan kepastian hukum bagi para tenaga medis khususnya saat menangani pasien terinfeksi virus menular.

\section{REFERENCES}

Afreeportamara, N W, and Pujiyono, 'Hambatan Kurator Dalam Menyelesaikan Piutang Koperasi Yang Diputus Pailit', Jurnal Hukum Dan Pembangunan Ekonomi, 7.2 (2019), 243-50 <https://jurnal.uns.ac.id/hpe/article/view/43014>

Ariyanto, Agung, Lego Karjoko, and Isharyanto, 'Politik Hukum Asas Non-Legally Binding Rekomendasi Ombudsman Republik Indonesia Sebagai Instrumen Pencegahan Dan Penanganan Laporan Maladministrasi', Jurnal Pasca Sarjana Hukum UNS, VII.1 (2019), 62-73

Bahar Elfudllatsani, Isharyanto, and Agus Riwanto, 'Kajian Mengenai Kebebasan Berkumpul Dan Berserikat Organisasi Kemasyarakatan Kaitannya Dengan Teori Kedaulatan Rakyat Dan Hak Asasi Manusia', Jurnal Pasca Sarjana Hukum UNS, VII.1 (2019), 52-61

Balenina, C.D., 'Partisipasi Masyarakat Dalam Pengelolaan Desa Sampah Mandiri Di Desa Kalisoro, Tawangmangu, Kabupaten Karanganyar', Bestuur, 7.1 (2019), 26-35 $<$ https://jurnal.uns.ac.id/bestuur/article/view/17392>

Estikomah, Solikah Ana, 'Aspek Hukum Import Sampah Plastik', Bestuur, 7.2 (2019), 106 <https://doi.org/10.20961/bestuur.v7i2.40439>

Eviningrum, Sulistya, 'Educative Penalty System as a Protection Implementation for Children Who Commit Crime', Journal of Morality and Legal Culture (JMCL ), 1.1 (2020), 38-44 <https://doi.org/10.20961/jmail.17i1.41087>

Handayani, I Gusti Ayu Ketut Rachmi, Lego Karjoko, and Abdul Kadir Jaelani, 'Model Pelaksanaan Putusan Mahkamah Konstitusi Yang Eksekutabilitas Dalam Pengujian Peraturan Perundang-Undangan Di Indonesia', Bestuur, 7.1 (2019), 36-46

Handayani, Otih, 'Implementation of Prudential Principles in the Use of Disinfectants as an Effort to Prevent Covid-19 Pandemic for Legal Protection of Ecosystems', Journal of Morality and Legal Culture ( JMCL ), 1.1 (2020), 58-65 <https://doi.org/10.20961/jmail.17i1.41087>

Hersriavita, Sara, 'UPAYA PENGEMBALIAN KERUGIAN NEGARA DARI PERKARA TINDAK PIDANA KORUPSI OLEH KEJAKSAAN NEGERI SUKOHARJO', Jurnal Hukum Dan Pembangunan Ekonomi, 7.1 (2019), 15-28

Iswantoro, 'Juridical Analysis of Environmental Law Enforcement in Forestry Crimes Regulation in the Regional Autonomy Iswantoro', Journal of Morality and Legal Culture ( JMCL ), 1.1 (2020), 45-49 <https://doi.org/10.20961/jmail.17i1.41087>

Ivnaini, Andesgur, 'Analisa Kebijakan Hukum Lingkungan Dalam Pengelolaan Pestisida', Bestuur, 7.2 (2019), 93-105

Jamil, M, 'Pemalsuan Akta Autentik Sebagai Aspek Pidana Notaris M.Jamil', Bestuur, 7.2 (2019), 114-21

Jumari, Arif, 'Potensi Pelanggaran Pengelolaan Limbah Bahan Berbahaya Dan Beracun Arif, Bestuur, 7.2 (2019), 76-83

Karjoko, Lego, Zaidah Nur Rosidah, and I Gusti Ayu Ketut Rahmi Handayani, 'Refleksi 
Paradigma Ilmu Pengetahuan Bagi Pembangunan Hukum Pengadaan Tanah', Bestuur, 7.1 (2019), 1-14 <https://doi.org/10.20961/bestuur.v7i1.42694>

Larasati, Mustika, and Arief Suryono, 'TINJAUAN YURIDIS ASURANSI JIWA TERHADAP KESELAMATAN', Jumal Pasca Sarjana Hukum UNS, VII.2 (2019), $236-42$

Muryani, Eni, 'Sinergisitas Penegakan Hukum Pada Kasus Pertambangan Emas Tanpa

Izin Di Kabupaten Banyumas, Jawa Tengah', Bestuur, 7.2 (2019), 84 <https://doi.org/10.20961/bestuur.v7i2.40437>

Nugraha, Riyan Aditya, Widodo Tresno Novianto, and Supanto, 'KARANGANYAR DALAM MEMUTUS PERKARA PIDANA HAK CIPTA GUNA MENCIPTAKAN KEPASTIAN HUKUM CIPTA ( Putusan', Jurnal Pasca Sarjana Hukum UNS, 7.1 (2011), 169-80

Pujiningsih, Sri, 'Policy Polemic for Covid 19 and Efforts to Handling Information Technology', Journal of Morality and Legal Culture (JMCL), 1.2 (2020), 93-102 <https://doi.org/10.20961/jmail.17i1.41087>

Rosidi Ruslan, 'COVID-19 Fulfilling Workers 'Economic Rights Positive', Journal of Morality and Legal Culture (JMCL), 1.2 (2020), 93-102 <https://doi.org/10.20961/jmail.17i1.41087>

Santoso, Arif Dian, Adi Sulistiyono, and Isharyanto, 'Majelis Kehormatan Disiplin Kedokteran Indonesia ( Mkdki) Untuk Dapat Menjamin Keadilan Dalam Hubungan Dokter Dan Pasien', Jurnal Pasca Sarjana Hukum UNS, VII.1 (2019), 29-38

Suprianto, Agus Riwanto, and Sunny Ummul Firdaus, 'Implementasi Peraturan Pemerintah Nomor 18 Tahun 2016 Tentang Perangkat Daerah Terhadap Efektivitas Kinerja Pegawai Sekretariat Daerah Dewan Perwakilan', Jurnal Pasca Sarjana Hukum UNS, VII.1 (2019), 134-43

Tanjung, Ahmad Kodir Jailani, Hari Purwadi, and Hartiwiningsih, 'Paradigma Hakim Dalam Memutuskan Perkara Pidana Di Indonesia', Jurnal Pasca Sarjana Hukum UNS, 7.1 (2019), 39-51 <https://jurnal.uns.ac.id/hpe/article/view/29178>

Wulandari, Febry, and Waluyo Waluyo, 'Efektivitas Pemanfaatan Dana Bagi Hasil Cukai Hasil Tembakau Dalam Bidang Kesehatan Di Kota Surakarta Tahun 2018', Bestuur, 7.1 (2019), 15-25 <https://doi.org/10.20961/bestuur.v7i1.28418>

Yatini, Hari Purwadi, and Hartiwiningsih, 'Reformulasi Konstruksi Pidana Dalam Menjerat Pelaku Tindak Pidana Korporasi', Pasca Sarjana Hukum UNS, VII.1 (2019), 144-52 